\title{
How to Understand non bis in idem?: The Element of idem According to the ECtHR
}

\section{non bis in idem Nasıl Anlaşılmalı?: idem Unsurunun AiHM'e Göre Yorumu}

\section{Tuba Kelep Pekmez ${ }^{1}$ ()}

\begin{abstract}
The European Court of Human Rights essentially has three approaches on the issue of the interpretation of idem within the context of the non bis in idem principle, namely "same conduct test", "essential elements test" and "same act test". These three interpretations are highly open to criticism. In this regard, it is clear that a new concept is necessary to distinguish act in terms of substantive criminal law and act in procedural criminal law practice. In order to determine what constitutes an idem, one should consider the concept of "procedural act". Moreover, I contend that providing a concrete and consistent interpretation of idem depends on the differentiation of the terms idem and same idem.
\end{abstract}

\section{Keywords}

Principle of non bis in idem, Concept of idem, Double jeopardy, Procedural act, Article 4 of Protocol No. 7 to the European Convention on Human Rights

Öz

Avrupa İnsan Hakları Mahkemesinin non bis in idem ilkesi bağlamında idem kavramının yorumlanmasında temel olarak üç yaklaşımı bulunmaktadır. Bunlar "aynı davranış testi", "esaslı unsurlar testi” ve "aynı hareket testi"dir. Bu üç yorum da eleştiriye son derece açıktır. Bu bağlamda maddi ceza hukuku ve ceza muhakemesi hukuklarının uygulanmasında fiil kavramının bu iki hukuk bakımından birbirinden ayrılması gereklidir. Neyin idem kavramını oluşturduğuna karar vermek için muhakemesel fiil kavramı göz önünde bulundurulmalıdır. Ayrıca idem kavramının somut ve tutarlı uygulanması idem ve aynı idem kavramlarının farklılaştırılması yoluyla sağlanacaktır.

\section{Anahtar Kelimeler}

non bis in idem ilkesi, idem kavramı, İki kere yargılama yasağı, Muhakemesel fiil, Avrupa İnsan Hakları Sözleşmesi Protokol $7 \mathrm{~m} .4$

\footnotetext{
1 Corresponding Author: Tuba Kelep Pekmez, (Res. Asst. Dr.), Istanbul University, Faculty of Law, Criminal and Criminal Procedural Law Department, Istanbul, Turkey. E-mail: tubakelep@gmail.com ORCID: 0000-0002-2042-2492

To cite this article: Kelep Pekmez, Tuba: "How to understand ne bis in idem ?: The element of idem according to the ECtHR", Annales de la Faculté de Droit d'Istanbul, 67, 2018, 31-41. https://doi.org/10.26650/annales.2018.67.0003 


\section{How to understand non bis in idem?: The element of idem according to the ECtHR}

\section{Introduction}

The non bis in idem principle ${ }^{1}$ is a fundamental individual right and a guarantee of legal certainty adopted by most legal systems ${ }^{2}$. It basically refers to the prohibition of bringing a case to the judicial bodies on the basis of the same idem ${ }^{3}$. Terminology may differ significantly depending on the law systems, which include non bis in idem; "double jeopardy" or "not to be tried or punished twice". As a result, the definition can be narrow or broad. Nevertheless, the core of the principle seems much the same, irrespective of the nomenclature ${ }^{5}$. In this sense, the scope of the application of the principle involves preventing not only multiple convictions but also multiple prosecutions or convictions depending on the same $i_{d e m^{6}}$.

The principle has both national and transnational aspects ${ }^{7}$, which means that it acts as a tool to prevent multiple prosecutions or convictions for the same idem not only within a national jurisdiction, but also allowing tates to approve its' transnational effect between different jurisdictions ${ }^{8}$. The principle is therefore recognized by

1 It is debatable whether the principle belongs to the "rule" or the "principle" category. For example, considering Dworkin's distinction of principles and rules, Bockel proposes the principle should be accepted as a rule. See: Bas Van Bockel, "The European ne bis in idem Principle: Substance, Sources, and Scope", Ne bis in idem in EU Law, Ed. by Bas Van Bockel, Cambridge University Press, 2016, p. 14., However, the author also states that traditionally it is convenient to approve it as a principle. See, Ibid, s. 14 .

2 Christine van den Wyngaert/ Guy Stessens, "The International Non Bis In Idem Principle: Resolving Some of the Unanswered Questions, The International and Comparative Law Quarterly, Vol: 48, No: 4, October 1999, p. 780; Maria Fletcher, "Some Developments to the ne bis in idem Principle in the European Union: Criminal Proceedings Against Hüseyn Gözütok and Klaus Brügge”, The Modern Law Review, Vol: 66, No: 5, September 2003, pp. 778.

3 Beck'scher Online Kommentar Grundgesetz, Ed. by: Epping/Hillgruber, 41. Ed., 2016, § 103, Rn. 44, Çevrimiçi https:// beck-online.beck.de/Dokument?vpath=bibdata\%2Fkomm\%2Fbeckokgg_40\%2Fgg\%2Fcont\%2Fbeckokgg.gg.a103.htm, 29.05.2019

4 Dionysios Spinellis, "Global Report the ne bis in idem Principle in "Global" Instruments", Revue international de droit pénal, Vol. 73, 2002/3, , p. 1149; Fletcher, Ibid, p. 770.

5 Linda E. Carter, "The Principle of Complementarity and the International Criminal Court: The Role of Ne Bis in Idem", Santa Clare Law Journal of International Law, Vol: 8, No: 1, 2010, p. 170.

6 Norel Neagu, "The Ne Bis in Idem Principle in the Interpretation of European Courts: Towards Uniform Interpretation", Leiden Journal of International Law, Vol: 25, 2012, p. 955.

7 On a domestic level, the main rationale of the principle has three dimensions. First, it provides protection for the individual. Second is the idea, that the criminal claim, after being considered once, is extinguished. And third, the principle embodies respect for judicial decisions. This is to prevent conflicting judgments. See Wyngaert/Stessens, Ibid, p. 780-781; These three rationales are virtually appropriate to be considered also in transnational level. See Ibid, p. 781-782. for similar evaluations see Bockel, Ibid, pp. 13-14.

8 José Luis de La Cuesta/ Albin Eser, "Concurrent national and international criminal jurisdiction and the principle "ne bis in idem"', Revue Internationale de Droit Pénal, Vol. 72, 2001/3-4, , p. 753; Spinellis, Ibid, p. 1150; It should also be noted that there is no generally accepted customary rule of international law or ius cogens providing an international protection of the principle in international situations. Therefore, international and transnational application of the principle appears in different forms (Bockel, Ibid, p.14; In this context, the content of the principle may differ in transnational level. For instance, it is accepted as a preventive closure for extradition under the European Convention on Extradition Article 9. In international level, the transnational effect of the principle can be observed under NATO Status of Forces Treaty (SOFA) Article VII (8), Article 54 and 55 Convention Implementing the Schengen Agreement or Article 20 of ICC (Rome) Statute. Besides these, as an individual right in international legal instruments concerning human rights, the principle is regulated under Article 4 of Protocol No. 7 to the Convention for the Protection of Human Rights and Fundamental Freedoms and Article 14 (7) of the International Covenant on Civil and Political Rights (ICCPR). It should also be stated that these two 
national laws ${ }^{9}$ and regulated under international conventions ${ }^{10}$.

In practice, the principle's primary and salient concern is the interpretation of the idem element. For this reason, the element of idem is regarded as the most controversial aspect of the principle ${ }^{11}$. Therefore, the terminology used to clarify the principle plays a significant role, and the scope and definition of the idem varies among jurisdictions and conventions ${ }^{12}$. The main question that arises here focuses on whether idem is relevant to a fact, an act or an offence in the context of the principle ${ }^{13}$. This differentiation in the application of the principle depends essentially on the tendency of European Court of Human Rights' (hereafter ECtHR) to prioritize the facts of the case; to the legal classification of those facts or to the legal interest being protected $^{14}$. Choosing a certain definition of the notion of idem may yield different results. For example, when the notion of idem is accepted as an offence, the first judgment for a certain fact but under a particular charge, would not prevent the person from being tried under the same facts but for different charges. On the other hand, if the principle is accepted to be applicable on the basis of the facts, the scope of effect would be much wider ${ }^{15}$.

conventions accept the effect of the principle only on a domestic level. This means it has a preventive role only for the judgments within the same state. Furthermore, in the context of international criminal law, the principle is considered in the Council of Europe Convention on the International Validity of Judgements and Council of Europe Convention on the Transfer of Proceedings in Criminal Matters; However, these two conventions are considered to be unsuccessful to establish an international non bis in idem principle because of the low ratification of these conventions by the members of the Council of Europe. (Fletcher, Ibid, p.770, fn. 7); Besides these, the two other instruments on the EU level related to the principle are the 1995 Convention on the Protection of the European Communities' Financial Interest and the 1997 Convention on the Fight against Corruption.

9 Some countries prefer the way to regulate the principle under their constitutions. See the Fifth Amendment to the US Constitution which states "(no) person (shall) be subject for the same offence to be twice put in jeopardy of life and limb"; Similarly, the German Basic Law (Grundgesetz) Article 103 paragraph. III reads as follows "No person may be punished for the same act more than once under general criminal law” (Çevrimiçi https://www.btg-bestellservice.de/pdf/80201000. pdf 17.01.2019)

10 The principle's effect between different states is called the horizontal effect, while the relation in terms of non bis in idem effect between national courts and the International Tribunals is named as the "vertical effect" of the principle. See, Spinellis, Ibid, p. 1152-1553; However, beside these, de La Cuesta and Eser asserts that there are three kinds of effect of the principle. See: de La Cuesta/ Eser, Ibid, p. 756.

11 Bockel, Ibid, p. 47.

12 For example Article 4 of Protocol No. 7 to the European Convention on Human Rights, Article 14 paragraph 7 of the United Nations Covenant on Civil and Political Rights, Article 50 of the Charter of Fundamental Rights of the European Union and the Fifth Amendment to the Constitution of the United States of America refer to the term as "same offence"; the American Convention on Human Rights prefers the term "same cause", the Convention Implementing the Schengen Agreement mentions "same act" and the Statute of the International Criminal Court adopts the terms "same conduct". See, Neagu, Ibid, p. 957.

13 Wolfgang Schomburg, "Ne bis in idem. Vom Auslieferungshindernis zum internationalen strafrechtlichen Doppelverfolgungsverbot als EU-Grundrecht. Eine Einführung anhand von Texten", "Ne bis in idem" in Europa, Ed. by: Gudrun Hochmayr, 1. Ed., Nomos, , 2015, p. 11; Marco Mansdörfer, Das Prinzip des ne bis in idem im europäischen Strafrecht, Dencker \&Humblot, Berlin, 2004, p. 23; Wyngaert/ Stessens, Ibid, p. 788; Neagu, Ibid, p. 555.

14 The Principle of Ne Bis in Idem in Criminal Matters in the Case Law of the Court of Justice of the European Union, (Çevrimiçi) http://www.eurojust.europa.eu/doclibrary/Eurojust-framework/caselawanalysis/The\%20principle \%20of $\% 20$ $\mathrm{Ne} \% 20 \mathrm{Bis} \% 20$ in $\% 20$ Idem $\% 20$ in $\% 20$ criminal\%20matters\%20in\%20the $\% 20$ case $\% 20$ law $\% 20$ of $\% 20$ the $\% 20$ Court $\% 20$ of\%20Justice $\% 20$ of\%20the\%20EU\%20(Sept.\%202017)/2017-09_CJEU-CaseLaw-NeBisInIdem_EN.pdf 27.03.2019; For example Court of Justice of the European Union and the Inter-American Court of Human Rights has been interpreted the notion in favor of the perpetrator on the grounds of the terms ( "same act" and "same cause") being used under related conventions. This approach strictly rejects the legal classification of the facts of the case and it depends on the material acts. In this way the protective scope of the principle is broadened. See: Neagu, Ibid, p. 957.

15 Wyngaert/ Stessens, Ibid, p. 789; Also see: Barış Bahçeci, "Vergi Cezalarında Ne Bis In Idem", Ankara Üniversitesi Hukuk Fakültesi Dergisi, Vol: 67, No: 2, 2018, p. 258. 
This paper aims to explain the interpretation of the ECtHR of idem by analyzing the main decisions and judgments of ECtHR on the matter.

\section{Interpretation of the ECtHR}

The non bis in idem principle is enshrined in Protocol No. 7 Article 4 of the European Convention on Human Rights:"no one shall be liable to be tried or punished again in criminal proceedings under the jurisdiction of the same State for an offence for which he has already been finally acquitted or convicted in accordance with the law and penal procedure of that State" ${ }^{16}$.

In applying this article, ECtHR faces three challenges ${ }^{17}$. Of the three, the two issues which are fundamental for this study are limiting the scope and qualification of sanctions within the article and deciding whether both proceedings were structurally criminal or penal; or determining whether there was a duplication of proceedings.. The third issue regarding the application of the non bis in idem principle which ECtHR dealt with is to interpret the notion of "an offence" in order to decide what constitutes an idem. ECtHR applied three different tests in order to determine whether the principle is applicable. These are the "same conduct" test, "essential elements" test and finally the "same act" test ${ }^{18}$.

\section{A. Same Conduct Test}

ECtHR initially followed the same conduct test that focuses on the material facts of the case and excludes the legal classification of those case-related facts. Thus, in this case the ECtHR placed the emphasis on identity of the facts ${ }^{19}$. In this manner, instead of considering whether the offences of cases considered by domestic courts are the same, the ECtHR evaluated whether the facts are the same and reached a decision according to those facts. It does not matter to the ECtHR if the provisions in question differed with respect to the designation or nature and purpose. Moreover, one provision may be the special version of another. Nevertheless, what is important to the ECtHR is that the two impugned decisions be based on the same conduct. In this sense, the ECtHR considers the overlapping of the facts as a violation ${ }^{20}$.

16 To decide whether or not there is a "criminal charge in the scope of the article ECtHR's' case law sets out three criteria These criteria are commonly known as "Engel criteria" which consists of a legal classification of the offence under national law, nature of the offence and degree of the severity of the penalty. See: Engel and Others v. the Netherlands, 8 June 1976; Also see European Court of Human Rights Factsheet-Non bis in idem, November 2018, (Emphasis added) https://www.echr.coe.int/Documents/FS_Non_bis_in_idem_ENG.pdf; In the last ten years there have been 19 violations to the breach of Protocol No 7 Article 4. These countries are: Azerbaijan (1 case), Bosnia and Herzegovina (1 case), Bulgaria ( 1 case), Finland (6 cases), Greece ( 2 cases), Iceland ( 1 case), Italy (1 case), Lithuania (1 case), Romania (1 case), Russia (1 case), Serbia (1 case), Sweden (1 case), Ukraine (1 case),

17 Guide on Article 4 of Protocol No. 7 to the European Convention on Human Rights, (Çevrimiçi) https://www.echr.coe.int/ Documents/Guide_Art_4_Protocol_7_ENG.pdf, 27.03.2019.

18 ECtHR has summarized these approaches in the Zolotukhin judgment. See Zolotukhin v. Russia, 10 February 2009, Para. 71-73; Also see: Neagu, Ibid, p. 969.

19 Guideline, Çevrimiçi https://www.echr.coe.int/Documents/Guide_Art_4_Protocol_7_ENG.pdf (28.03.2019)

20 Gradinger v. Austria, 23 October 1995, Para. 55. 
The exemplary application at this point is the Gradinger judgment. In this case, the applicant caused an accident that resulted in a cyclist's death. Later at the hospital, it was detected that he/she had an alcohol level of 0.8 grams per liter in his/her blood. The applicant was punished pursuant to Article 81 of the Criminal Code and the Road Traffic Act. The applicant alleged that it was a violation of non bis in idem principle by fining him/her under the Road Traffic Act ${ }^{21}$. ECtHR found an infringement of Article 4 of Protocol No. 7 in view of the fact that the both decisions had been based on the same conduct by the applicant ${ }^{22}$.

However, as regards cases where "ideal concurrence of offences" is discussed, ECtHR is of the opinion that Article 4 of Protocol 7 prohibits persons being tried for the same offence, but on the legal classification, accepts that the same facts could lead to different offences ${ }^{23}$. In such cases, ECtHR ruled that there was no breach of Article 4 of Protocol 7, as not only the conduct, but also the offences should be identical. For example, in the case of Oliveira, ECtHR adopted this approach by taking the legal qualification of the underlying facts as the criterion for establishing the identity of the "offence" without considering the factual elements of the overlapping cases $^{24}$. In the applicant's submission, the fact that he/she was convicted of the same incident first for failing to control his/her vehicle and subsequently for negligently causing physical injury, constituted an infringement of Article 4 of Protocol No. $7^{25}$.

\section{B. Essential Elements Test}

Following these controversial judgments, as in the Franz Fischer case and myriad subsequent decisions, ECtHR employed an application of the notion by considering whether two or more offences shared the same "essential elements" ${ }^{26}$. In Fischer, where ECtHR found a violation of Article 4 of Protocol No. 7, it affirmed that the administrative offence of "drink driving" and the crime of "causing death by negligence while allowing himself to be intoxicated" had the same essential elements $^{27}$. ECtHR stated that:

the wording of Article 4 of Protocol No. 7 does not refer to "the same offence" but rather to trial and punishment "again" for an offence for which the applicant has already been finally acquitted or convicted. Thus, while it is true that the mere

21 Gradinger v. Austria, 23 October 1995, Para. 48.

22 Gradinger v. Austria, 23 October 1995, Para. 55.

23 Oliveira v. Switzerland, 30 July 1998, Para. 26.

24 Franz Fischer v. Austria, 29 August 2001, Para. 21.

25 Oliveira v. Switzerland, 30 July 1998, Para. 22; Subsequently in the case of Göktan ECtHR found no violation because the same conduct of the applicant constituted two separate offences. See Göktan v. France, 2 July 2002, Para. 52; For similar cases see: Gauthier v. France 24 June 2003,) and Öngün v. Turkey, 10 October 2006.

26 Bockel, Ibid, p. 47; Guideline, Çevrimiçi https://www.echr.coe.int/Documents/Guide_Art_4_Protocol_7_ENG.pdf (28.03.2019); Bahçeci, Ibid, p. 261;

27 Franz Fischer v. Austria, 29 May 2001, Para. 30. 
fact that a single act constitutes more than one offence is not contrary to this Article, the Court must not limit itself to finding that an applicant was, on the basis of one act, tried or punished for nominally different offences. The Court, ... notes that there are cases where one act, at first sight, appears to constitute more than one offence, whereas a closer examination shows that only one offence should be prosecuted because it encompasses all the wrongs contained in the others ${ }^{28}$.

However, this approach is criticized for weakening the protection of the principle of Article 4 of Protocol No. 7 and giving rise to legal uncertainty ${ }^{29}$. In particular, this criticism gave rise to the interpretation of the phrase "the same essential elements"

In addition to the above, a different set of "essential elements" featured in ECtHR's analysis in two Austrian cases. In the Hauser-Sporn case ECtHR held that the offence of abandoning a victim and the offence of failing to inform the police about an accident differed in their criminal intent and also concerned different acts and omissions ${ }^{31}$. And in the Schutte case the "essential element" of one offence was the use of dangerous threat or force as a means of resisting the exercise of official authority, whereas the other concerned a simple omission in the context of road safety, namely the failure to stop at the request of the police ${ }^{32}$. Finally, in a similar application on the subject, ECtHR ruled that the two offences in question had different "essential elements" in that they were distinguishable in terms of their gravity and consequences. These "essential elements" were determined as the social value being protected and the criminal intent $t^{33}$.

\section{Same Act Test}

After all these decisions, the ECtHR's interpretation gained stability and shifted interpretation to a more accurate level. As a matter of fact, for almost ten years ECtHR has used this approach for the solution of the problem. In the Zolotukhin case ECtHR adopted its current factual approach to the definition of $i_{d e m^{34}}$. In this sense, the terminology used in the interpretation of the concept is not deemed significant $t^{35}$. It has also been argued that ECtHR has developed a more harmonized standard test rather than a test for "essential elements"

28 Franz Fischer v. Austria, 29 May 2001, Para. 25; For similar cases see: W.F. v. Austria, 30 May 2002; Sailer v. Austria, 6 June 2002; Manasson v. Sweden, 8 April 2003; Bachmaier v. Austria, 2 September 2004.

29 Bockel, Ibid, s. 48.

30 Bahçeci, Ibid, p. 262.

31 Hauser-Sporn v. Austria, 7 December 2006, Para. 43-46.

32 Schutte v. Austria, 26 July 2007. Para. 42.

33 Garretta v. France, 4 March 2008.

34 Zolotukhin v. Russia, 10 February 2009.

35 Bas Van Bockel, "Introduction and Set-Up of the Study", Ne bis in idem in EU Law, Ed. by:Bas Van Bockel, Cambridge University Press, 2016, p. 6.

36 Elisa Ravasi, Human Rights Protection by te ECtHR and the ECJ: A Comparative Analysis in Light of the Equivalency Doctrine, Boston Brill, 2017, p. 247. 
In this judgment ECtHR first noted that

"the existence of a variety of approaches to ascertain whether the offence for which an applicant has been prosecuted is indeed the same as the one of which he or she was already finally convicted or acquitted engenders legal uncertainty incompatible with a fundamental right, namely the right not to be prosecuted twice for the same offence. "37.

ECtHR thus related the interpretation of the principle before the law to the interests of legal certainty, foreseeability and equality ${ }^{38}$. In this regard, it first analysed the notion in the context of other international instruments incorporating the principle. And then it stated that the use of the word "offence" in Article 4 of Protocol No. 7 cannot justify adhering to a more restrictive approach. According to ECtHR, the Convention must be interpreted and applied in a way that is both "practical and effective" 39 . ECtHR was therefore of the opinion that Article 4 of Protocol No. 7 must be understood as prohibiting the prosecution or trial of a second "offence" in so far as it arises from identical facts or facts which are substantially the same ${ }^{40}$.

In order to determine whether the facts in both proceedings were identical or substantially the same, the statement of facts should concern both the offence for which the applicant had already been tried and the offence against which he or she is accused ${ }^{41}$.

ECtHR also stressed that it was irrelevant in the subsequent proceedings that parts of the new charges were eventually upheld or dismissed. Accordingly, its investigation should focus on those facts that constitute a set of concrete factual circumstances involving the same defendant and inextricably linked together in time and space, the existence of which must be demonstrated in order to secure a conviction or institute criminal proceedings ${ }^{42}$.

\section{Comments and Conclusion}

It could be said that three of ECtHR's approaches to the concept of idem are open to significant criticism. For example, "same conduct test" basically considers the historical events that constitute the charge and entirely excludes substantive criminal law's concepts. This approach could lead to unjust solutions and could also have

37 Zolotukhin v. Russia, ECtHR 10 February 2009, Para. 78.

38 Zolotukhin v. Russia, ECtHR 10 February 2009 Para.78.

39 Zolotukhin v. Russia, ECtHR 10 February 2009 Para.80.

40 Zolotukhin v. Russia, ECtHR 10 February 2009 Para.82; This interpretation originally belongs to European Court of Justice. For this reason, it is stated that ECtHR has adopted this interpretation from the decisions of the European Court of Justice. See, Neagu, Ibid, p. 971.

41 Zolotukhin v. Russia, ECtHR 10 February 2009 Para.83.

42 Zolotukhin v. Russia, ECtHR 10 February 2009 Para.83-84. 
the potential to lengthen the criminal procedure in an unpredictable way. Besides, "essential elements test" is also controversial, since it takes into account the elements of crime in the substantive criminal law but lacks certain and determinable criteria to explain which elements of an offence are essential. And finally, the "same act test" can also be considered as a return to a limited "same conduct test", since in the "same conduct test" only the historical events, which are the facts of the case according to ECtHR, should be considered but this time these facts should be identical or substantially the same as each other

In this regard, it is obvious that a new concept is necessary to distinguish act in terms of substantive and procedural criminal law practice. In order to determine what constitutes an idem, one should consider the concept of procedural act. This term refers to "Strafprozessuale Tatbegriff" in German law and is related to the "procedural subject matter" (Prozessgegenstand) of the case ${ }^{43}$. The procedural subject matter of the case has two elements: one is the subjective element which is the defendant person, and the other one is the objective element which is the procedural act ${ }^{44}$. It is important to correctly and concretely detect the objective and subjective elements of one specific case, in order to determine whether these elements are overlapping with those of another case. It should also be noted that the idem element of the non bis in idem principle refers to the objective element of the procedural subject matter.

The early decisions of ECtHR on the issue were contradictory and inconsistent. In this sense, various approaches can be noted in its case law ${ }^{45}$. I contend that providing a concrete and consistent interpretation of idem depends on the differentiation of the terms idem and same idem.

On the one hand, idem is the procedural act and, aside from all the debates and various views on the issue, is accepted as the "historical incident" limited to the indictment ${ }^{46}$. The historical incident should be limited in terms of the conduct, perpetrator, time, space, subject, instrument and victim ${ }^{47}$. Therefore, idem should be considered as a purely factual concept which has no relation to the substantive criminal law's regulations ${ }^{48}$. On the other hand, in addition to the limitations in the determination of idem, detecting the same idem also requires an evaluation of the

43 Roxin/ Schünemannn, Strafverfahrensrecht, 29. Bs. München, Beck, 2017, § 20, Rn. 2; Urs Kindhäuser, Strafprozessrecht, 3. Ed., 2013, § 25, Rn. 1.

44 Roxin/ Schünemannn, Ibid , § 20, Rn. 3; Kindhäuser, Ibid, § 25, Rn. 2.

45 Bockel, The European ne bis bin idem principle, p. 47; Xavier Groussot/ Angelica Ericsson, "Ne bis in Idem in the EU and ECHR Legal Orders A Matter of Uniform Interpretation", Ne bis in idem in EU Law, Ed. by: Bas Van Bockel, Cambridge University Press, 2016, pp. 56.; Neagu, Ibid, p. 969.

46 For detailed debates and views on the issue see Luis Greco, Strafprozesstheorie und materielle Rechtskraft: Grundlagen und Dogmatik des Tatbegriffs, des Strafklage, verbrauchs und derWiederaufnahme im Strafverfahrensrecht, Berlin, Duncker \& Humblot, 2015 s. 440 vd.

47 Kyung-Lyul Lee, Die Präzisierung der "Tateinheit" und Reichweite des Strafklage, verbrauchs nach der Entscheidung BGHSt 40, 138 zum "Fortsetzungszusammenhang", Berlin, Logos, , 2002, s. 197.

48 Ibid, p. $198 \mathrm{ff}$. 
substantive criminal law. The decisive and limiting factor taken from substantive criminal law should be the legally protected value element. The legally protected value will result in a fairer application of the non bis in idem principle as it determines the legal issue defined by an offence ${ }^{49}$. Otherwise, the effect of non bis in idem would prevent justice from being manifested. In this respect the legal value of an offence which is under protection of a certain offence, should be the same or similar. If the legal values are the same or similar, idem of two certain cases are considered "the same" and non bis in idem effect of the latter case can be observed.

It must be noted that, unlike the ECtHR, being practical should not be a concern in terms of human rights protections. Thus, one should consider whether the result is fair or not in applying the non bis in idem principle. Although the principle of Zolotukhin is said to need a practical interpretation, it is more important to implement the principle fairly. For this reason, legally protected values should be taken as a basis, which are relatively less practical and give a fairer result. It would not be wrong to accept that ECtHR's approach in Zolotukhin as a more practical one. However, the approach in the "essential elements" test is much more suitable to ensure justice for the parties.

In summary, when applying the essential element test, the essential element does not have to be an element of a crime, but it should be considered as the legally protected value of an offense. Therefore, it is understandable for ECtHR to use the same act test to determine the concept of idem, while limiting it. However, it must return to the application of the essential element test, taking into account the legally protected value which is an essential element in terms of the same application. For this reason, ECtHR's interpretation in Zolotukhin should be applied as the definition of the idem in the broader sense, but in order to decide whether there is same idem in a case, ECtHR should return to the essential elements test and investigate whether the legally protected values are the same as the essential elements.

Grant Support: The author received no grant support for this work.

\section{Bibliography}

\section{Books \& Articles}

Bahçeci, Barış: "Vergi Cezalarında Ne Bis In Idem", Ankara Üniversitesi Hukuk Fakültesi Dergisi, Vol: 67, No: 2, 2018, pp. 253-278.

Bockel, Bas Van: "Introduction and Set-Up of the Study", Ne bis in idem in EU Law, Ed. by: Bas Van Bockel, Cambridge University Press, 2016, pp. 1-12.

Bockel, Bas Van: "The European ne bis in idem Principle: Substance, Sources and Scope",Ne bis in idem in EU Law, Ed. by: Bas Van Bockel, Cambridge University Press, 2016, pp. 13-53.

49 Greco, Ibid, $460 \mathrm{ff}$. 
Carter, Linda E: "The Principle of Complementarity and the International Criminal Court: The Role of Ne Bis in Idem", Santa Clare Law Journal of International Law, Vol: 8, No: 1, 2010, pp. 165-198.

de La Cuesta José Luis / Eser Albin : "Concurrent national and international criminal jurisdiction and the principle 'ne bis in idem"', Revue Internationale de Droit Pénal, Vol. 72, 2001/3-4, pp. 753-764.

Fletcher, Maria: "Some Developments to the ne bis in idem Principle in the European Union: Criminal Proceedings Against Hüseyn Gözütok and Klaus Brügge”, The Modern Law Review, Vol. 66, No. 5, September 2003, pp. 769-780.

Greco, Luis: Strafprozesstheorie und materielle Rechtskraft: Grundlagen und Dogmatik des Tatbegriffs, des Strafklage, verbrauchs und derWiederaufnahme im Strafverfahrensrecht, Berlin, Duncker \& Humblot, 2015.

Groussot Xavier / Ericsson Angelica: "Ne bis in Idem in the EU and ECHR Legal Orders A Matter of Uniform Interpretation", Ne bis in idem in EU Law, Ed. by: Bas Van Bockel, Cambridge University Press, 2016, pp. 53-102.

Kindhäuser, Urs: Strafprozessrecht, 3. Auflage, 2013.

Lee, Kyung-Lyul: Die Präzisierung der "Tateinheit" und Reichweite des Strafklage, verbrauchs nach der Entscheidung BGHSt 40, 138 zum "Fortsetzungszusammenhang”, Logos, Berlin, 2002.

Mansdörfer, Marco: Das Prinzip des ne bis in idem im europäischen Strafrecht, Dencker \& Humblot, Berlin, 2004.

Neagu, Norel: "The Ne Bis in Idem Principle in the Interpretation of European Courts: Towards Uniform Interpretation”, Leiden Journal of International Law, Vol. 25, 2012, pp. 955-977.

Ravasi, Elisa: Human Rights Protection by te ECtHR and the ECJ: A Comparative Analyisis in Light of the Equivalency Doctrine, Boston Brill, 2017.

Roxin/ Schünemannn: Strafverfahrensrecht, 29. Ed,. München, Beck, 2017.

Schomburg, Wolfgang: Germany, "Concurrent National and International Criminal Jurisdiction and the Principle "ne bis in idem"”, Revue Internationale de Droit Pénal, Vol. 73, 2002/3, pp. 941-964.

Schomburg, Wolfgang: "Ne bis in idem. Vom Auslieferungshindernis zum internationalen strafrechtlichen Doppelverfolgungsverbot als EU-Grundrecht. Eine Einführung anhand von Texten", "Ne bis in idem" in Europa, Ed. by: Gudrun Hochmayr, Nomos, 2015, pp. 9-26.

Spinellis, Dionysios: "Global Report the ne bis in idem Principle in "Global” Instruments", Revue international de droit pénal, Vol. 73, 2002/3, pp. 1149-1162.

Wyngaert, Christine van den / Stessens, Guy: "The International Non Bis In Idem Principle: Resolving Some of the Unanswered Questions", The International and Comparative Law Quarterly, Vol: 48, No: 4, October 1999, pp. 779-804.

\section{Online Resources}

Beck'scher Online Kommentar Grundgesetz, Herausgegeben von Epping/Hillgruber, 30. Ed. 2016, § 103, Rn. 44 (BeckOK GG/Radtke-Hagemeier, §103). https://beck-online.beck.de/ Dokument?vpath=bibdata\%2Fkomm\%2Fbeckokgg_40\%2Fgg\%2Fcont\%2Fbeckokgg.gg.a103. htm 
The Principle of Ne Bis in Idem in Criminal Matters in the Case Law of the Court of Justice of the European Union, (Çevrimiçi) http://www.eurojust.europa.eu/doclibrary/Eurojustframework/caselawanalysis/The $\% 20$ principle $\% 20$ of $\% 20 \mathrm{Ne} \% 20 \mathrm{Bis} \% 20 \mathrm{in} \% 20 \mathrm{Idem} \% 20$ in $\% 20$ criminal $\% 20$ matters $\% 20$ in $\% 20$ the $\% 20$ case $\% 20$ law $\% 20$ of $\% 20$ the $\% 20$ Court $\% 20$ of $\% 20$ Justice\%20of\%20the\%20EU\%20(Sept.\%202017)/2017-09_CJEU-CaseLaw-NeBisInIdem_ EN.pdf 27.03.2019

https://www.btg-bestellservice.de/pdf/80201000.pdf 17.01.2019

https://www.echr.coe.int/Documents/FS_Non_bis_in_idem_ENG.pdf

Guide on Article 4 of Protocol No. 7 to the European Convention on Human Rights, (Çevrimiçi) https://www.echr.coe.int/Documents/Guide_Art_4_Protocol_7_ENG.pdf, 27.03.2019

\section{Cases}

Bachmaier v. Austria, 2 September 2004.

Engel and Others v. the Netherlands, 8 June 1976.

Franz Fischer v. Austria, 29 May 2001.

Garretta v. France, 4 March 2008.

Gradinger v. Austria, 23 October 1995.

Hauser-Sporn v. Austria, 7 December 2006.

Sailer v. Austria, 6 June 2002.

Manasson v. Sweden, 8 April 2003.

Oliveira v. Switzerland, 30 July 1998.

Schutte v. Austria, 26 July 2007.

W.F. v. Austria, 30 May 2002.

Zolotukhin v. Russia, 10 February 2009. 
